\title{
Development of Inclusive Society with the Instruments of "green" Economy and Education
}

\author{
Inha Ziankova \\ Department of Economics \\ Polotsk State University \\ Novopolotsk, Belarus \\ i.zenkova@psu.by
}

\author{
Alena Lisichonak \\ Department of Economics \\ Polotsk State University \\ Novopolotsk, Belarus \\ lena_pit@tut.by
}

\author{
Aliaksandr Yemialyanau \\ Department of Economics \\ Polotsk State University \\ Novopolotsk, Belarus \\ Emelianovik@mail.ru
}

\begin{abstract}
The article substantiates that in order to ensure the effective development of economic systems, the issues of rational use of natural resources and environmental safety are significant. Environmental problems for modern economies of the world are systematized. The aim of the research is to study the theoretical and practical experience in the formation of an inclusive society and the "green" economy of the regions in the Republic of Belarus based on the analysis of the mechanism for introducing circular technologies at the micro level, schemes for engaging vulnerable groups of the population, creating "green" jobs, creating courses on the principles of inclusion economy in the workplaces. The following tasks were set and resolved: the mechanism for the formation of the inclusive society and the "green" economy in the Republic of Belarus was identified through the introduction of circular technologies at the micro level; considered the features of involvement in employment of vulnerable groups of the population; identified and systematized features of creating "green" workplaces; specificity of courses for on-the-job training on the principles of inclusion and "green" economy is grounded. The research methodology is based on the principles of systems analysis, formal logic and an interdisciplinary scientific approach. Monographic and descriptive method was used in the formation of theoretical and practical basis for development an inclusive society with elements of the "green" economy; method of analysis and synthesis, method of statistical data analysis in the shortterm analysis. The novelty of this research lies in the fact that the theoretical and practical foundations for building the inclusive society through the tools of the "green" economy and education have been studied and scientifically grounded. The conclusions are that the creation of "green" jobs, learning the principles of a "green" economy, as well as the implementation of other measures to ensure the sustainable development are necessary. And development of inclusive society and "green" economy depend on ability of government and firms to teach their basic principles and create inclusive and "green" workplaces and jobs. As recommendations it is proposed to involve older labor resources in employment, taking into account coordination of the vocational qualification structure of labor supply and technical and technological parameters of workplaces; to assess development of the international labor market and sustainable development of the labor market with created by authors list of indicators; to develop an electronic web resource with information about the skills of the workforce, indicating the geography of workplaces and schemes for building up the necessary skills contributes to the advance preparation of the workforce; and to organize and conduct courses for employers and employees in the field of inclusive development and "green" jobs.
\end{abstract}

Keywords-Effective employment, "green" economy, inclusive society, inclusive education.

\section{INTRODUCTION}

An inclusive society is seen as a society in which conditions are created for people with special needs and disabilities to lead an independent lifestyle and actively participate in all aspects of life and development of such a society.

The labor market is developing in the formation of a circular economy. Such an economy involves the rational use of labor resources. Global risks are discussed at the Davos Economic Forum (The RiskTrends Interconnections). Such risks are associated with unemployment and underemployment. The reason is seen in the not fully use of the potential of the employed population. The situation is complicated by the aging of society, social instability, age polarization of society.

Studies in the field of forecasting the labor potential of various countries and regions are conducted by leading international organizations. Research results are reflected in economic models and projects, for example, The Labor Market Development Project, The Staff Studies for the World Economic Outlook, The Cohort-Based Model of Labor Force Participation. People of older working age are actively involved in the process of creating value added and for a long time remain the economically active part of the population. The article highlights the difficulties of the older generation in the labor market. They are:

-low awareness of available vacancies and job requirements;

- difficulties in acquiring new competencies.

The article substantiates the involvement of older labor resources in employment, taking into account:

- features of the circular economy and global risks of the world community;

- coordination of the vocational qualification structure of labor supply and technical and technological parameters of workplaces;

- features of gender and age characteristics of the types of aging society. 
Consideration of these factors will allow:

-support the creation of jobs with high added value;

- rational distribution of labor resources of the necessary qualifications and gender characteristics;

- rationally distribute labor resources by traditional and / or innovative sectors of the economy.

The novelty of this research lies in the fact that the theoretical and practical foundations for building the inclusive society through the tools of the "green" economy and education have been studied and scientifically grounded.

\section{MATERIALS AND METHODS}

Studying of documents of global importance on productive and full employment (Global Jobs Pact, ILO) showed that indicators "... increasing employment, production and investment and aggregate demand and ensuring decent work for all ..." are important for inclusive economic growth.

The approach is valuable by highlighting young women and men in the labor supply structure. According to the ILO, “... every year about 45 million young women and men enter the global labor market, mainly in developing countries ..." [1].

Analysis of the documents revealed the tools to achieve full and productive employment. They are:

-stimulating labor demand;

-supporting of labor resources actively looking for work;

-supporting for the unemployed;

-consultation with employers and employees [1].

Examination of global documents (Resolution adopted by the General Assembly on September 25, 2015 of the United Nations) also shows that youth employment issues are being updated on the global labor market.

In the article's noted the importance of the employment of young people of different levels of education, the aspects of self-employment of young people in entrepreneurial activities [2].

The study of the global document (Work Program 2018-2020, Horizont 2020) showed that the labor market is developing in the conditions of the formation of a circular economy [3].

For the development of the international labor market, it is highlighted the following indicators: decent quality work, employment indicator, involvement in the economy, labor market efficiency [4].

The authors offer as indicators of the sustainable development of the labor market: elasticity between employment and output growth by sectors of the economy, an index of dependents in the country [5].

The research methodology is based on the principles of systems analysis, formal logic and an interdisciplinary scientific approach. Monographic and descriptive method was used in the formation of theoretical and practical basis for development an inclusive society with elements of the "green" economy; method of analysis and synthesis, method of statistical data analysis in the shortterm analysis.

\section{RESULTS AND DISCUSSION}

The authors distinguish a pattern: with hard labor laws, staff turnover decreases, and the devaluation of skills during a cyclical recession also decreases. Noted the conclusion that the high level of unemployment benefits is an additional incentive for workers to accept the risk of preserving human capital. The presence of sectoral skills in workers contributes to high skill at workplaces and intensive production, productive work. Authors point out the following category - internal flexibility of the labor market. It manifests itself as follows: the employee takes overtime during the peak of the economic cycle. The employer is responsible for maintaining the number of the employed labor force and raising professional qualifications during the economic downturns.

It is concluded that the factors of external inflexibility of the labor market are:

1) the reactivity of monetary and fiscal policies to adapt to fluctuations in the economic cycle;

2) the amount of government spendings and their impact on the value of aggregate demand.

Identified factors of labor supply in the labor market. They are:

- changes in income distribution;

- regulation in the credit market;

-quality of social protection;

-the ratio of private and public funding in the education system;

- employee qualification (ratio of specific skills to general skills),

-reaction ability of monetary, fiscal policy in cyclical unemployment.

Methodological principles for achieving productive employment for inclusive economic growth are substantiated. They are the following:

1) if the growth rate of the real interest rate is lower than the growth rate of labor productivity, then it contributes to the formation of real financial wealth (rentier);

2) reduction of overhead costs for firms contributes to the shift in income distribution in favor of labor with a stimulating effect on aggregate demand;

3) financial policy contributes to achieving full employment and even distribution of disposable income.

The formation of the institutional framework of the labor market to combat the devaluation of labor skills has been proposed. It is electronic web resource with 
information about the skills of the workforce, indicating the geography of workplaces and schemes for building up the necessary skills contributes to the advance preparation of the workforce.

It is concluded that for sustainable and balanced global economic growth, it is necessary to create high-quality jobs. Therefore, the authors point out the following economic indicators:

-crisis jobs;

-strengthening the ability of workers to adapt to the future needs of the labor market;

-development of employment as the basis of economic growth;

-training of workers to benefit from new investments. It is about investments to clean energy production, healthcare and infrastructure;

-increasing the share of salary in the cost structure,

-labor productivity growth;

-reducing income inequality;

-creating "green" workplaces (in frames of "green" economy) [1].

Among the problems faced by humanity at this stage of development, a special group stood out the issues of environmental management and environmental protection, i.e. "environmental problems". One of the options for achieving the necessary balance of "humanecology-society" is outlined in the idea of creating a fundamentally new approach to managing human activities of the so-called "green" economy.

The importance of studying of "green" economy formation in regions and organizations of Belarus is connected with the need for sustainable development.

According to L. Kuzina [6], "an analysis of the final documents adopted at the United Nations Conference on Sustainable Development "RIO +20 " allows to come to the conclusion that the world community accepts inevitability of replacement of market model of progress on new, or "green" economy. Most often, the "greening" of the economy is understood as ensuring economic growth and improving the well-being of people while preserving the environment.

Many developed countries have already begun to develop concrete strategies for the transition to a "green" economy. The National Strategy for the Sustainable Socio-Economic Development of Belarus until 2030 aims to implement the principles of "green economy" in practice [7]. At the same time, the circular component of the "green" economy does not receive enough attention from both the government and business. Creating conditions for "green" growth is considered by the Ministry of Economy to be an essential tool for attracting foreign investment.

Currently, the country is implementing a number of projects, for example:

- "Development of the forest sector of Belarus"
- implemented through a World Bank loan (\$ 40.7 million) and a related grant from the Global Environment Facility (\$2.7 million).

- "Promoting Belarus's transition to a "green" economy" is funded by the European Union and implemented by the United Nations Development Program. The total project budget is 5 million euros. The project started in 2015.

Belarus is a participant of the program (project) "Greening the Economy in the Eastern Partnership Countries of the European Union" (national coordinators are the Ministry of Economy and the Ministry of Natural Resources and Environmental Protection), jointly implemented by United Nations Economic Commission for Europe, the Organization for Economic Cooperation and Development, United Nations Environment Programme and United Nations Industrial Development Organization.

Belarus has developed a National Action Plan for the development of the "green" economy in the Republic of Belarus until 2020 [8]. One of the publications from the series of works on the circular economy in Belarus, carried out in the framework of the Development Project of the Center for Economic Research BEROC prepared by N. Batova, P. Sachek and I. Tochitskaya [9]. The authors revealed that the "green" economy is one of the instruments for achieving sustainable development, and the circular economy is the practical basis for its implementation.

Next, it is considered the features of the introduction of the circular technologies mechanism at the level of regions and organizations. The authors will base on the fact that, in the opinion of N. Batova, P. Sachek and I. Tochitskaya, the important features of the "green" economy are a steady decline in all types of negative impacts, including pollution; preventing the loss of ecosystem services and biodiversity; the innovative nature of economic dynamics, income growth and employment; a drastic reduction in poverty, and in a circular economy, priority is given to the lower consumption of resources from the environment, as well as their lesser return to the environment as waste.

The research object chosen by the authors corresponds to one of the sectors covered at the UN conference on sustainable development "RIO + 20" "Sustainable cities and the environment". Next, it is considered how the principles of a "green" and circular economy are implemented in one of the largest industrial centres of Belarus - Novopolotsk city.

The authors analyses the indicators characterizing the features of the formation of a "green" and circular economy, using data from the National Statistical Committee of Belarus [10] It is reflected in table I. 
TABLE I. INDiCATORS CHARACTERIZING THE FEATURES OF “GREEN" AND CIRCULAR ECONOMY FORMATION IN NOVOPOLOTSK IN COMPARISON WITH INDICATORS OF THE VITEBSK REGION AND BELARUS

\begin{tabular}{|l|c|c|c|}
\hline \multirow{2}{*}{ Name of the indicator } & \multicolumn{3}{|c|}{ Value of the indicator in 2017 } \\
\cline { 2 - 4 } & $\begin{array}{c}\text { in } \\
\text { Novopo- } \\
\text { lotsk }\end{array}$ & $\begin{array}{c}\text { in } \\
\text { Vitebsk } \\
\text { region }\end{array}$ & $\begin{array}{c}\text { in the } \text { Re- } \\
\text { public of } \\
\text { Belarus }\end{array}$ \\
\hline $\begin{array}{l}\text { 1. The unemployment rate reg- } \\
\text { istered (end of year), as a per- } \\
\text { centage of the labor force }\end{array}$ & 0,8 & 0,7 & 0,5 \\
\hline $\begin{array}{l}\text { 2. Real wages, as a percentage } \\
\text { of the previous year }\end{array}$ & 105,8 & 105,7 & 107,5 \\
\hline $\begin{array}{l}\text { 3. Emissions of pollutants into } \\
\text { the air from stationary sources, } \\
\text { tons per organization } \\
\text { tons per person }\end{array}$ & 70,92 & 7,93 & 3,20 \\
\hline $\begin{array}{l}\text { 4. Production waste generation } \\
\text { tons per organization } \\
\text { tons per person }\end{array}$ & 0,48 & 0,09 & 0,01 \\
\hline $\begin{array}{l}\text { 5. Volume of water used } \\
\text { thousand cubic meters per or- } \\
\text { ganization } \\
\text { thousand cubic meters per per- } \\
\text { son }\end{array}$ & 78,33 & 12,24 & 8,94 \\
\hline
\end{tabular}

Source: made and calculated by authors based on data of National Statistical Committee of the Republic of Belarus

The features of the formation of a "green" and circular economy in Novopolotsk are due to the functioning on its territory of the largest industrial organization Open Joint-Stock Company Naftan, which produces various types of fuels, lubricating oils and bitumens, aromatic hydrocarbons and petrochemical products.

So, Novopolotsk is characterized by significant amounts of pollutant emissions into the air from stationary sources both per organization and per inhabitant. At the same time, the unemployment rate exceeds the average for the Vitebsk region and for Belarus as a whole. The growth rates of real wages in Novopolotsk as a whole correspond to its growth rates in the Vitebsk region and are significantly lower than the average for Belarus. Thus, for Novopolotsk, the formation of a "green" economy is undoubtedly an important and urgent task, since it causes significant harm to the environment. This negatively affects the standard of the population living of the region, despite the fact that the growth rates of real incomes are insignificant here, and unemployment exceeds the average level in the state and the region.

Referring to the features of the circular economy, it should be noted that the volume of water use in Novopolotsk in 2017 significantly exceeds similar figures for the Vitebsk region and Belarus, that is, there is significant water consumption. At the same time, the volume of waste generation on average corresponds to the average regional level and is significantly lower than the average national level. That is a problem for the city is significant water consumption.

In general, it should be noted that the formation of both a "green" and a circular economy is relevant for Novopolotsk, since there is a threat to the sustainable development of the region, caused by significant consumption of certain types of resources, the negative impact of industry on the environment unemployment and insufficiently high growth rates of real wages.

Creation of inclusive society and "green" economy is closely connectedto the education sphere.

Education as a social institution plays an exceptional role in the development of the individual and its socialization. Today, the features of each are considered as an undeniable value, as a potential for socio-economic development as a whole. The construction of modern society is based on an understanding of the developing potential of diversity, the significance of the contribution of each to a single process of improvement.

Inclusive education is a chance to create a tolerant, open and personal-oriented society, with equal conditions of development for all its members, regardless of abilities and opportunities. The disadvantages of inclusive education are the psychological unreadiness of society to accept a person with disabilities, the imperfection of the system of social support and the provision of such persons and persons with disabilities.

In this regard, it is necessary to organize and conduct courses for employers and workers in the field of inclusive development.

Inclusive education is based on the following principles:

- systemic - inclusive education is a systemic phenomenon in education, covers the entire education system, applicable at all levels and in all types of education;

- complexity - inclusive education causes changes in the whole complex of relationships in the educational institution, implies coordinated activities of specialists;

- accessibility - inclusive education requires adaptation of the educational environment for any category of students;

- variability and consideration of the specific educational needs of each student;

- tolerance - inclusive education involves the formation of relationships based on understanding, accepting and respecting existing differences, recognizing equal rights.

Combining a labor resource with a social combination of production factors is limited by the reluctance of employers to hire people with disabilities, the lack of regular and accessible information about available vacancies, and segregation. The society, having incurred the cost of forming the labor resource of a disabled person, is waiting for its return, which requires jobs and other opportunities for the realization of the labor resource. The lack of interest of an entrepreneur to use a non-competitive labor resource of a disabled person should be compensated by creating conditions in which the entrepreneur agrees to present jobs to people with disabilities. 
Ways of inclusion of persons with disabilities in the socio-economic relations of employment and the use of their labor resources are unique and depend not only on the conditions of the region, but also on the inherent limitations of labor opportunities.

Education plays a key role in effectively using the tools and mechanisms of the "green" economy in practice. Education as a social institution is the most important of the basic conditions for the transition to a "green" economy, since it contributes to the support and dissemination of innovations, both technological, economic and socio-cultural. It is the ability of society to generate new ideas and approaches to solving problems and having the opportunity to demonstrate the effectiveness of these innovations and their widespread introduction becomes the key to the competitiveness of national economies.

In the same way, education in the interests of a "green" economy can play the role of a supplier to the labor market of new personnel or retraining of some of the former. In the course of the development of "green" industries in the labor market, the demand for specialists of new professions - the so-called "green collars" - is increasing [11].

At the moment, staff shortages in specialists in "green" industries are already felt, for example, there is a shortage of personnel in the biofuels sector in Brazil, in renewable energy and the production of environmental goods and technologies in Germany, the USA and Bangladesh, in the construction sector in Australia, China, Europe and South Africa [12].

In addition to specific qualifications and competencies related to employment in the sector of environmental goods and services, the task of "greening" all labor capital in all sectors and at all levels is no less important. In general, in terms of content, approaches and methods, education for a "green" economy is first of all education for change, since the transition to sustainable development and a "green" economy requires abandoning outdated forms of management, changing not only formal rules (government policies, legislation), but also informal (business ethics, social norms and values). Under new conditions, education requires efficiency in the preparation of creative initiative individuals who are able to solve complex problems in innovative and flexible ways. And for this, first of all, the transition from the reproductive to the creative approach in the organization of the educational system and the educational process, as well as in the content and methods of teaching, is required.

It is highly necessary to improve cooperation between universities and sectoral departments in order to match training programs (both students and civil servants) with government priorities.

\section{CONCLUSIONS}

It was concluded that it is important to increase the so-called "green skills" in time for the emerging "green" jobs.
It is substantiated that production itself is fragmentary and is built in different economic systems. This entails the distribution of labor skills across countries.

It has been substantiated that the scope of the services market allows developing self-employment for people of different skill levels.

The conclusion was made and substantiated that in order to ensure inclusive economic growth, taking into account the fragmentation of production, the creation of production chains for the production of different added value, it is necessary to take into account a number of indicators. They are the following:

- analysis of the national economy on the current and possible rates of savings and the mentality of nations, as well as their desire to invest in self-employment and the creation of GDP;

- structure of the total population by age and gender;

- the proportion of the working population in the total population;

- share of exports in the production of each of the national economies;

- the proportion of labor costs in the structure of the gross domestic product;

- on the ability of national economies to create jobs through the coefficient of capital growth (the size of gross investment to change in real GDP);

- size of infrastructure investments (size of investments in tangible infrastructure networks: transport, energy, and intangible infrastructure networks: education, research costs);

- productivity of services in production and in the service sector;

- the share of GDP by sectors of the economy to assess the contribution of changes in sectoral employment to the growth of total employment;

- elasticity between employment and output growth by sector to assess changes in sectoral employment depending on an increase in sectoral output by 1 percentage point.

Authors offer to develop an electronic web resource with information about the skills of the workforce, indicating the geography of workplaces and schemes for building up the necessary skills contributes to the advance preparation of the workforce.

Taking into account the importance of education in modern economic development it is necessary to organize and conduct courses for employers and employees in the field of inclusive development and "green" jobs.

Creation of "green" jobs, learning the principles of a "green" economy, as well as the implementation of other measures to ensure the sustainable development are necessary. Development of inclusive society and "green" economy depend on ability of government and firms to teach their basic principles and create inclusive and "green" workplaces and jobs. 


\section{REFERENCES}

[1] International Labor Office, "Global Jobs Pact: Policy Coherence and International Coordination." Geneva: ILO, 2009. [Online]. Available: https://www.ilo.org/wcmsp5/groups/public/---ed norm/---relconf/documents/meetingdocument/wcms 116773.pdf. [Accessed: Dec. 20, 2018].

[2] United Nations, "Transforming our world: the 2030 Agenda for Sustainable Development.” Brussels: UN, 2015. [Online]. Available: http://www.un.org/en/development/desa/population/migration/generalassembly/docs/globalcompact/A_RES_70_1_E.pdf. [Accessed: Dec. 20, 2018].

[3] European Commission, "Work Programme 2018-2020: Horizon 2020. Climate action, environment, resource efficiency and raw materials (C (2018)4708).” Brussels: EC, 2017. [Online]. Available: http://ec.europa.eu/research/participants/data/ref/h2020 wp/2018-2020/main/h2020-wp1820-climate en.pdf. [Accessed: Jan. 19, 2019].

[4] World Economic Forum, "Committed to Improving the state of the World, The human capital report 2016," World Economic Forum, 2016. [Online]. Available: http://www.iberglobal.com. [Accessed: Jan. 19, 2019].

[5] M. Lavoie and E. Stockhammer, Wage-led Growth. An Equitable strategy for economic recovery. London: Palgrave Macmillan and ILO, 2013.

[6] L. Cousin. "Green economy as an alternative existing market economy," Forest messenger, no. 4, pp. 37-42, 2015.

[7] Ministry council of the Republic of Belarus, "National Strategy for Sustainable Social and Economic Development of the Republic of Belarus for the period up to 2030,"'Ministry council of the Republic of Belarus, 2017 [Online]. Available: http://www. economy.gov.by/uploads/files/NSUR2030/Natsionalnaja-strategija-ustojchivogo-sotsialno-ekonomicheskogo-razvitija-Respubliki-Belarus-na-period-do-2030-goda.pdf [Accessed Jan. 20, 2019]

[8] Ministry of natural resources and environmental protection of the Republic of Belarus, "National Action Plan for the Development of a Green Economy in Belarus until 2020," Ministry of natural resources and environmental protection of the Republic of Belarus, 2017. [Online]. Available: http://minpriroda.gov.by/uploads files/1061r-1-2.doc [Accessed: Jan. 20, 2019].

[9] N. Batova, P. Sachek, I. Tochitskaya, "On the road to green growth: a window opportunities circular economy," BEROC Green Economy Policy Paper Series, pp GE no.1, 2018

[10] National Statistical Committee of the Republic of Belarus, "Environmental protection in Belarus," National Statistical Committee of the Republic of Belarus, 2018 [Online]. Available: http:// www.belstat.gov.by/ofitsialnaya-statistika/publications/izdania/ index 9417/. [Accessed Dec. 21, 2019].

[11] A. Kaminov. "Green economy: education as a transition factor," IX correspondence international scientific-practical conference, May 30-31, 2015, Ekaterinburg, Russia. Ekaterinburg: UrFU, 2015

[12] European Centre for Development of Vocational Training (Cedefop). "Future skill needs for the green economy," European Centre for Development of Vocational Training (Cedefop), 2009. [Online]. Available: http://www.cedefop.europa.eu/EN/Files/5501 en.pdf[Accessed: Jan. 24, 2019]. 